\title{
8. Reflections on Gender and Small Languages in World Literature Scholarship: Methods of Inclusions and Exclusions $^{1}$
}

Katarina Leppänen

History of Ideas, University of Gothenburg

An overarching question in my research as a scholar working in small languages in the Nordic countries concerns how world literature studies can promote localised and gendered knowledge. Firstly, gendered perspectives informed by feminist literary studies are, as I will argue, often totally absent or activated only as a political context rather than as an analytical literary category. Secondly, smaller languages seem to evaporate in highly globalised scholarly practices. Is world literature a field with specific analytical tools, designed in a manner that is incommensurable with the aims and methods of feminist analysis where conjunctions of social, economic and political powers intersect in texts? This way of understanding texts as political could, following Gayatri Spivak, be termed "a socially grounded view of comparative literature and

I This chapter is a considerably abbreviated and rewritten version of the article by Jenny Bergenmar and Katarina Leppänen, "Gender and Vernaculars in Digital Humanities and World Literature", NORA: Nordic Journal of Feminist and Gender Research, 25, no. 4 (20I7).

How to cite this book chapter:

Leppänen, Katarina. "Reflections on Gender and Small Languages in World Literature Scholarship: Methods of Inclusions and Exclusions". In World Literatures: Exploring the Cosmopolitan-Vernacular Exchange, edited by Stefan Helgesson, Annika Mörte Alling, Yvonne Lindqvist, and Helena Wulff, 89-99. Stockholm: Stockholm University Press, 20I8. DOI: https:// doi.org/ıo.16993/bat.h. License: CC-BY. 
world literature". ${ }^{2}$ In two recent projects in transnational literary history focusing on women writers, such as the HERA project Travelling Texts (I790-I9I4). Transnational Reception of Women's Writing at the Fringes of Europe and Swedish Women Writers on Export in the Nineteenth Century, the latter based at my home department at Gothenburg University, neither world literature nor digital humanities provide unconditionally useful research methods or theories, because they lack sufficient tools for multilingual analysis in diverse sources. ${ }^{3}$ Although world literature scholars at times challenge the western canon, the forgotten writers in these projects may not be seen as a priority since they are western (even if they are not canonical).

This chapter will approach world literature through three themes that have been central to my research: quality, representation and transfer/translation. In the following I will let these concepts introduce some key aspects of my approach to the research programme.

\section{Quality}

Unqualified use of the idea of literary quality as an element inherent in the text runs countercurrent to the understanding of literature presented here. Quality has to be politically, culturally and socially grounded. As intellectual historian Mikela Lundahl writes in an article on canon and democracy, for every canonical text there are countless excluded, forgotten and silenced texts. Her point is that these texts, the ones yet to be recovered, potentially become valuable because they shed new light on the emergence of our aesthetic ideals. ${ }^{4}$

2 Gayatri Chakravorty Spivak and David Damrosch, "Comparative Literature/World Literature: A Discussion", in World Literature in Theory, ed. David Damrosch (Chichester: Wiley Blackwell, 2014), 363 .

3 See further Bergenmar and Leppänen, "Gender and Vernaculars".

${ }^{4}$ Mikela Lundahl, "Kanon och demokrati", in Kanon ifrågasatt: Kanoniseringsprocesser och makten över vetandet, eds. Katarina Leppänen and Mikela Lundahl (Möklinta: Gidlunds, 2009), I7. 
Lundahl highlights the multiple effects that minor or peripheral texts may have on our understanding of canon and quality: There are yet undiscovered texts that could, hopefully, be included in the canon, and, even more importantly, the non-canonical texts are highly relevant for understanding canon formation per se.

However, Zhang Longxi, for example, argues in an ardent defence of world literature studies, that the field offers a unique opportunity for nations to present "canonical works because they are by definition the best and most exemplary works of different literary traditions". ${ }^{5}$ Zhang rejects outright any reason other than the aesthetic (as if this were a neutral unit of measurement) to include literature in the world literature canon. He does acknowledge the existence of a critical discussion on western canon, embraces the idea of a geographically expanding canon that can include non-western texts, yet no other expansion is neither expected nor desirable. Postcolonial literary studies are almost totally rejected as simply "political" and as making unwarranted claims of ethical superiority, "women and minority writers ... cannot become canonical simply because they have been overlooked or neglected in the past". ${ }^{6}$ Zhang's position may be extreme, yet, as Castillo's argument shows in the next section, quality arguments have not only been central since Goethe's Weltliteratur, but are still unproblematically used. Zhang's article is published in the very first volume of the Journal of World Literature, an issue that also hosts an article by Mads Rosendahl Thomsen. Rosendahl Thomsen's perspective is rather different from Zhang's when he highlights the importance of "current topics that are already making a significant impact on the future shape of international circulation of literary works, as well as the continuous canonization of works that circulate as world literature of the past". ${ }^{7} \mathrm{He}$ mentions migration and networked identities, digital interfaces, climate change, and the posthuman horizon, suggesting that the

5 Longxi Zhang, "Canon and World Literature”, Journal of World Literature I, no. I (2016), I22.

6 Zhang, "Canon and World Literature", I 25, I 2 I.

7 Mads Rosendahl Thomsen, "Grand Challenges! Great Literature?" Journal of World Literature, I, no. I (2016), 97. 
subject matter is also a measure of quality. Gender is, however, not listed as a current topic that would significantly influence world literature or world literary history. Perhaps this phenomenon can be understood through Damrosch's exposition of the displacement of texts in relation to the canon. The hypercanon, Damrosch argues, consists of "major" authors (one imagines a Shakespeare or a Joyce), the countercanon consists of the new postcolonial/world authors (one imagines a Rushdie or a Pamuk). The shadowcanon is, however, the most interesting category when it comes to gender because it consists of "the old 'minor' authors who fade increasingly into the background". ${ }^{8}$ No women authors are mentioned explicitly as having been left in the shadows, but considering their position as minors in relation to the old canon, this can at least partly explain the position of women authors and the absence of gender theories in world literature studies. Thus, national recovery projects of lost or forgotten authors, including women writers, need to be stepped up to the world literature scale.

Comparative literature, as an academic field, David Damrosch states in an article in PMLA, is haunted by a "specter of amateurism" due to the impossibility of any one person to grasp the world's languages and cultures. ${ }^{9}$ One may, of course, claim that there is a risk of a different kind of "amateurism" when it comes to the presumed canonical works, that is, of a near total contextual insensitivity. By this I mean that in an eagerness to make claims regarding a text's universal appeal or thematics, its worldliness, the spatial and temporal uniqueness may be lost. While in some sense "objective" (as in a given aesthetic yardstick for the canonical, or a superior method of large-scale text mining in digital humanities), such methods risk making the achieved results rather meaningless. Matthew Jockers, for example, includes gender as an analytical category in Macroanalysis and finds that "female authors are far more likely to write about women, and they use the female pronouns her and she far more often than

${ }^{8}$ David Damrosch, "World Literature in a Postcolonial, Hypercanonical Age", in Comparative Literature in an Age of Globalization, ed. Haun Saussy (Baltimore: Johns Hopkins University Press), 45.

9 David Damrosch, "Comparative Literature”, PMLA I I 8, no. 2 (2003), 326. 
their male counterparts". ${ }^{\circ}$ Interesting indeed, but hardly cutting-edge research results, if such findings are not theorised and contextualised. That is, such findings risk cementing hierarchical and already widely spread misogynist understandings of "women who only write about women", if not followed by questions of "why", "how" and "where". There is a whole corpus of feminist literary theory analysing, exploring and explaining the rise of the novel, the domestic themes and the female characters, and the political meanings and implications of such texts, that large-scale digital humanities and world literary studies need to relate to.

\section{Representation}

"Silences enter the process of historical production at four crucial moments", writes anthropologist and postcolonial scholar Michel Rolph Trouillot, "the moment of fact creation (the making of sources), the moment of fact assembly (the making of archives) the moment of fact retrieval (the making of narratives); and the moment of retrospective significance (the making of history in

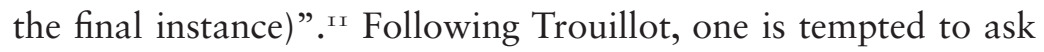
the question of absence of gender in world literature, historically, theoretically and numerically. His observation speaks, of course, both to canonisation and representation.

The compilation of readers and companions is a central issue because, in effect, such compilations create and construct world literature studies as a university subject by making a selection of texts available in a collected volume, in a given language. A look at the larger English language companions shows that gender hardly figures at all as an analytical category. Neither is gender a category of analysis in any prominent readers, nor in major methodological handbooks. It is, of course, not a novel insight that there are more men than women in world literature - anything else would be astounding. But just as astounding is the near total

ro Matthew Jockers, Macroanalysis: Digital Methods and Literary History (Urbana, Chicago \& Springfield: University of Illinois Press, 2013), 93.

II Michel-Rolph Trouillot, Silencing the Past: Power and the Production of History (Boston: Beacon Press, I995), 26. 
absence of gender and/or feminism, with the exception of those with special focus on women. ${ }^{\text {I2 }}$

The issue is addressed critically by Debra A. Castillo in her article "Gender and Sexuality in World Literature" in the Routledge Companion to World Literature (2012). Castillo's survey concludes that roughly 20 per cent of the included works are written by women. Women appear in specific sections of the anthologies, primarily in the sections of women authors, indigenous authors or among the non-western authors. "Suggestively", Castillo writes, "the particular selection of all three of these non-Western sections implicitly ask us to think of how genre is associated with race as well as with gender, highlighting, perhaps, more vernacular, more personally charged, more overtly ideological forms...". ${ }^{\text {I3 }}$ The selection in other sections is, unsurprisingly, based on "enduring aesthetic principles", Castillo concludes. ${ }^{\mathrm{I}}$ It is as if, when elevated to a world scale, the social dimensions of texts have to either be diminished (universalisable texts), or become the sole or primary frame of interpretation.

Although Castillo does not use the word, this is of course an argument based on literary quality, something women through history have had a hard time achieving or proving. Tellingly, the Routledge Companion to World Literature where Castillo's analysis appears, only indexes "gender" as appearing in Castillo's own article. Feminism, by comparison, is not listed at all. World Literature in Theory (2014) has no index but none of the chosen articles focus gender or feminism, while What is World Literature? has an overly generous interpretation of "gender and politics", listing at times the very mentioning of women in the book.

An interesting literary history project with a different approach to representation is the History of the Literary Cultures of

\footnotetext{
${ }^{12}$ See, for example, Deborah Weagel, Women and Contemporary World Literature: Power, Fragmentation and Metaphor (New York: Peter Lang, 2009).

I3 Debra Castillo, "Gender and sexuality in world literature", in Routledge Companion to World Literature, eds. Theo D'haen, David Damrosch and Djelal Kadir (London: Routledge, 20I 2), 40 I.

${ }^{14}$ Castillo, "Gender and sexuality", 4OI.
} 
the East-Central Europe: Junctures and Dis-junctures in the Nineteenth and Twentieth Centuries (2004-2010). In its attempt to apply a comprehensive transnational approach to the vast cultural and literary region that stretches from the Baltic countries to Albania, from Ukraine to the Czech Republic, it offers a prismatic, multicultural, and multimedia model of literary history, an "experiment in writing literary history that acknowledges ruptures as well as transnational connections". ${ }^{\text {Is }}$ Commencing from a spectrum of themes, languages, genres and geographies, the volumes constantly construct and reconstruct the region, though its literary cultures. The effect of such an approach to this region that is truly multi-everything - language, religion, nation, politics opens for reading culture in several directions simultaneously. What can be left out in such an approach are the restrictions posed by national borders, as nation itself does not become a dominant frame of interpretation, even though nation is never totally unimportant, given the role literary culture played in the very formation of nations. Of course, at the periphery of this periphery, other border zones are neglected, for reasons related to scope and aim.

\section{Translation/transfer}

There is an interesting tension between specialist knowledge (for example of different national literatures such as Marcel CornisPope's and John Neubauer's project above that engages I 20 scholars) and the generalist tendencies. David Damrosch, a generalist sensitive to the virtues of specialism, argues that "the generalist should feel the same ethical responsibility towards specialized scholarship that a translator has towards a text's original language" ${ }^{16}$ Gayatri Spivak, a strong advocate for specialism reflects on how the plurality of languages and literatures can be secured at our universities only by genuine and in-depth knowledge of both literature and culture. She deplores Damrosch's idea of achieving

is Marcel Cornis-Pope, "Literary History in Transnational Mode: The Challenges of Writing a History of East-Central European Literatures", Comparative Literature Studies, 50, no. 2 (2013): 204.

${ }^{16}$ Damrosch, "Comparative Literature", 202. 
more generalist skills, "more languages and more language studies", by accepting a "sliding scale" of knowledge and using, among other things, a diverse student body in the classroom as a resource. ${ }^{17}$ Instead, comparative studies and world literature studies require high standards of language skills, cultural orientation and skills for reading "in the most robust sense". ${ }^{18}$

Translation studies have become an essential part of comparative literature, with its discussions of the translatability or untranslatability of ideas, cultures and texts. Emily Apter "activate[s] untranslatability as a theoretical fulcrum of comparative literature" that has bearings on all aspects of large scale or comparative studies, from "world literatures", "the translation of philosophy and theory" to "ethical, cosmological and theological dimensions of worldliness". ${ }^{19}$ Apter rejects, firstly, ideas about cultural equivalence and substitutionality and, secondly, nationally and ethically branded differences. ${ }^{20}$ Translation can never be understood simply as a conversion of one language to another, it must rather be seen as an intricate intellectual challenge, an endeavour through which world literature scholars can deprovincialise the canon and draw "on translation to deliver surprising cognitive landscapes hailing from inaccessible linguistic folds" ${ }^{21}$ The idea of the translation as an intellectual activity that fundamentally changes the texts stands in stark contrast to how translations are used in the writing of literary history with computational methods, and also in the study of world literature, Apter contends. To be able to study world literature, translations are a necessary medium, since few scholars or students master more than a few languages sufficiently well.

For me, coming from intellectual history rather than a literary discipline, Apter's contestation of translation and her devotion to

\footnotetext{
${ }^{17}$ Spivak and Damrosch, "Comparative Literature/World Literature", 368-69.

I8 Spivak and Damrosch, "Comparative Literature/World Literature", 376.

I9 Emily Apter, Against World Literature: On the Politics of Untranslatability (London: Verso, 2013), 3-4.

${ }^{2 \circ}$ Apter, Against World Literature, 2.

2I Apter, Against World Literature, 2.
} 
the messiness of translation is appealing for several reasons. The question of small languages is perhaps obvious as translation is a requirement of reaching an audience of any considerable size. Conceptual translations are part of translation in general but hold a deeper significance when it comes to political and national(-ist) concepts such as gender, nation and people, to name a few. A future task is to investigate such conceptualisations in the Nordic-Baltic region. From the viewpoint of translationality and transferability, renewed focus can be given to the regional. How is the translation of literature from one small peripheral language to another small peripheral language part of the nation formation?

When social dimensions of texts, such as genres, genders and languages, are discussed, there are several feminist theoretical challenges that could inform world literary studies. Margaret Higonnet contends that to include gender in literary analysis is "to trace historical shifts and cultural differences for which the scholarship is still evolving". ${ }^{22}$ The social context of both text and text production must be seen as culturally and politically embedded and as developing differently across cultures. Gender studies can, furthermore, offer a shift in "understanding a self that is complex, many-layered, projected and performed in a constant shifting process". ${ }^{23}$ A consequence of such a re-thinking of identity as neither solid nor permanent makes it much less interesting to group or categorise texts according to apparently permanent or essentialising categories (such as nation, language, gender, indigenous), which, as Castillo shows, is still being done. In this chapter, I have pointed out some challenges I see in combining the world literature field with my research interests in small languages and gender.

The research programme Cosmopolitan and Vernacular Dynamics in World Literatures approaches world literatures as a field of exchange between the global and the local by investigating the fundamental inter-dependency of, and generative tension between, cosmopolitan and vernacular trajectories in literary

\footnotetext{
${ }^{22}$ Margaret Higonnet, "Introduction", Comparative Critical Studies 6 (2009), I35.

23 Higonnet, "Introduction”, I 37.
} 
cultures. In this dynamic, world literary scholarship holds an unfulfilled promise where translation becomes the most consequential sites of negotiation between the cosmopolitan and the vernacular. Studying literature in more than I 5 languages, the contestation is that world literature is that which comprise both cosmopolitan and vernacular dimensions, rather than a world literature canon. Although the project displays few explicitly feminist theoretical trajectories it opens for understanding the social and political aspects of literary culture. I especially hope that the research programme will open for a deepened interest in the social and political implications of unreflected references to the canon, to universality and to translation, regarding both localised linguistic expression and embodied gendered experiences.

\section{Bibliography}

Apter, Emily. Against World Literature: On the Politics of Untranslatability. London: Verso, 2013.

Bergenmar, Jenny and Leppänen, Katarina. "Gender and Vernacular in Digital Humanities and World Literature". NORA: Nordic Journal of Feminist and Gender Research 25:4 (20I7): 232-46.

Castillo, Debra. "Gender and Sexuality in World Literature”. In The Routledge Companion to World Literature, edited by Theo D'haen, David Damrosch and Djelal Kadir, 393-403. London: Routledge, 20I2.

Cornis-Pope, Marcel and Neubauer, John. History of the Literary Cultures of the East-Central Europe: Junctures and Dis-junctures in the Nineteenth and Twentieth Centuries. Vol. I-4. Amsterdam and Philadelphia: John Benjamins, 2004-2010.

Cornis-Pope, Marcel. "Literary History in Transnational Mode: The Challenges of Writing a History of East-Central European Literatures". Comparative Literature Studies 50:2 (2013): 204-210.

Damrosch, David. "Comparative literature". PMLA II 8, no. 2 $(2003): 326-33$.

What Is World Literature? Princeton and Oxford: Princeton University Press, 2003. 
Damrosch, David. "World Literature in a Postcolonial, Hypercanonical Age". In Comparative Literature in an Age of Globalization, edited by Haun Saussy, 43-53. Baltimore: Johns Hopkins University Press, 2006.

Higonnet, Margaret. "Introduction". Comparative Critical Studies 6 (2009): I35-48.

Jockers, Matthew. Macroanalysis: Digital Methods and Literary History. Urbana, Chicago \& Springfield: University of Illinois Press, 2013.

Longxi, Zhang. "Canon and World Literature". Journal of World Literature I, no. I (2016): I I9-27.

Lundahl, Mikela. "Kanon och demokrati". In Kanon ifrågasatt: Kanoniseringsprocesser och makten övervetandet, edited by Katarina Leppänen and Mikela Lundahl, I3-50. Möklinta: Gidlunds, 2009.

Rosendahl Thomsen, Mads. "Grand Challenges! Great Literature?" Journal of World Literature I, no. I (2016): 97-106.

Spivak, Gayatri Chakravorty and David Damrosch. "Comparative Literature/World Literature: A Discussion”. In World Literature in Theory, edited by David Damrosch, 363-88. Chichester: Wiley Blackwell, 20I4.

Trouillot, Michel-Rolph. Silencing the Past: Power and the Production of History. Boston: Beacon Press, I995.

Weagel, Deborah. Women and Contemporary World Literature: Power, Fragmentation and Metaphor. New York: Peter Lang, 2009. 
